\title{
Exploring the Relationships among Sustainable Manufacturing Practices, Business Performance and Competitive Advantage: Perspectives from a Developing Economy
}

\author{
Suzana N. Russell ${ }^{1} \&$ Harvey H. Millar ${ }^{2}$ \\ ${ }^{1}$ Centre for Production Systems, University of Trinidad and Tobago, Trinidad W.I. \\ ${ }^{2}$ Sobey School of Business, Saint Mary's University, Halifax, Nova Scotia, Canada \\ Correspondence: Suzana N. Russell, Centre for Production Systems, University of Trinidad and Tobago, \\ O’Meara Campus, 78-94 O’Meara Industrial Estate, Arima, Trinidad W.I. Tel: 1-868-642-8888. E-mail: \\ suzana.russell@utt.edu.tt
}

Received: July 3, $2014 \quad$ Accepted: August 1, $2014 \quad$ Online Published: August 29, 2014

doi:10.5539/jms.v4n3p37 URL: http://dx.doi.org/10.5539/jms.v4n3p37

\begin{abstract}
This study aims to empirically test the relationships among the adoption of sustainability practices, business performance and competitive advantage in Caribbean manufacturing firms. Seven dimensions of sustainable manufacturing practices are conceptualized and tested against measures of business performance and competitive advantage. Three hypothesized relationships are tested using the partial least squares structural equation modeling (PLS-SEM) technique. The results show a negative relationship between the adoption of sustainability practices and business performance. We also find that there is no significant relationship between the adoption of sustainability practices and competitive advantage. However, we observe a significant positive relationship between competitive advantage and business performance. Based on these findings, manufacturing firms in developing regions, such as the Caribbean, are advised to pursue sustainability strategy implementation with some vigor, but should base their choices on strategies that will enhance sustainability through improved resource productivity, while improving business performance and competitive advantage.
\end{abstract}

Keywords: business performance, Caribbean, competitive advantage, partial least squares structural equation modeling, sustainable development

\section{Introduction}

Sustainability has been emerging as a new means to achieve competitive differentiation for many companies (Shahbazpour \& Seidel, 2006). Effective sustainable manufacturing practices have now become a potentially valuable way of securing competitive advantage and improving organizational performance (Vinodh \& Joy, 2011). However, in spite of the fact that sustainable manufacturing has been frequently promoted as a means of improving business competitiveness, little empirical evidence exists in the literature validating a positive link with organizational performance (Vinodh \& Joy, 2011). As such, the ever-present question is whether there is in fact a direct positive relationship between the adoption of sustainability practices, business performance and competitive advantage; that is, whether companies emphasizing a sustainability strategy and adopting sustainability practices outperform other companies that do not.

More than a decade has passed since Klassen and Whybark (1999) point out that customers, suppliers, and the public are increasingly demanding that businesses in general, and manufacturing firms in particular, minimize any negative impact of their products and operations on the natural environment. Since then, the ability of organizations to manage their environmental performance is emerging as a strategic issue for firms (Henri \& Journeault, 2008). Gombauldt and Versteege (1999) identify some drivers for companies engaging in sustainability practices such as cost reduction, quality improvement, regulatory requirements and competition. Firms may also become proactive in anticipation of more efficient utilization of resources and improved corporate image (Montabon, Sroufe, \& Narasimhan, 2007). Regardless of the reason for adopting sustainability practices, it is clear that more companies are viewing sustainability as an opportunity for competitive advantage. What is less clear from the extant literature is the extent to which the adoption of sustainability practices impacts business performance and competitive advantage. This is because the literature has generally produced mixed 
results as a number of empirical studies in this area ${ }^{1}$ have returned differing verdicts (Russo \& Fouts, 1997). Some studies have shown a positive relationship between environmental performance and firm performance, for example, Aragón-Correa, Hurtado-Torres, \& García-Morales (2008), Klassen and McLaughlin (1996), Nakao, Amano, Matsumura, Genba, \& Nakano (2007), and Russo and Fouts (1997). Other studies such as Cordeiro and Sarkis (1997), Wagner (2005), Walley and Whitehead (1994), and Watson, Klingenberg, Polito, \& Geurts (2004) argue that there is a conflict between competitiveness of firms and their environmental performance and show a negative relationship. The existing literature therefore provides a mixed message to business managers, policy makers and other stakeholders who are interested in protecting the environment through promoting corporate responsible behaviors (Zeng, Meng, Yin, Tam, \& Sun, 2010).

Researchers cite various reasons for the differing results among these empirical studies. Claver, López, Molina, \&Tarí (2007) attribute the disparity in the results to a consequence of the type of variables used in the different studies, the methods applied to measure them and the partial or isolated treatment given to some of the variables. Wagner (2001) also points to the different methodological issues and the different measures used for environmental performance, which illustrates the difficulty in comparing empirical studies. Consequently, it is reasonable to say that few studies, if any, use similar measures to represent environmental performance as according to Xie and Hayase (2007), there is a lack of agreement on what and where to measure. Schaltegger and Synnestvedt (2002) suggest that another reason for the conflicting results of the various empirical studies may be the lack of a clear theoretical framework within which to investigate the links between environmental performance and economic performance.

This paper proposes to empirically test the relationships among the adoption of sustainable manufacturing practices, business performance and competitive advantage for Caribbean manufacturers. Although the Caribbean region may be relatively small in terms of population its economic environment is similar to several other developing regions, such as Latin America and parts of Asia and Africa, and as such may provide some useful insights. The manufacturing industry is chosen for this study because as Handfield, Walton, Seegers, \& Melnyk (1997) point out, this is where environmental business practices are more likely to be found. Moreover, the industry is often criticized as a major cause of many social and environmental problems (Zeng et al., 2010), producing more air, land, and water pollution than service facilities (Stead \& Stead, 1992). This study addresses three primary research questions: Do Caribbean manufacturing firms with higher levels of adoption of sustainable manufacturing practices have higher levels of business performance? Do Caribbean manufacturing firms with higher levels of adoption of sustainable manufacturing practices have higher levels of competitive advantage? Do Caribbean manufacturing firms with higher levels of competitive advantage have higher levels of business performance? In addressing these questions, the primary contribution of this paper is to add to the empirical research on the impact of the adoption of sustainability practices on dimensions of business performance and competitive advantage. The paper is based on a survey of the sustainability practices of manufacturing firms in 5 Caribbean countries. The 5 countries selected account for the majority of manufacturing in the Caribbean region. This paper is important as Zeng et al. (2010) point to the fact that very few studies have examined this relationship in the context of developing economies. We believe our findings can help to provide some guidance to firms in other developing regions around the world operating in similar economic environment. As such, a second contribution of this paper is to complement existing literature focusing on developing countries. To our knowledge, there is no previous work looking at sustainability practices and business performance among Caribbean manufacturing firms and the lingering question seems to remain: does it really pay for Caribbean manufacturing firms to be green? This paper also contributes to the literature by focusing on micro-approaches or operational level practices since the use of aggregated measures tends to provide less information about particular environmental practices (Rusinko, 2007). Our study therefore aims to operationalize the sometimes vague concept of sustainable manufacturing into specific practices that have value at the operations level.

The rest of the paper is organized as follows. Section 2 presents the research framework and defines the multidimensional constructs of sustainable manufacturing practices, business performance and competitive advantage. The hypothesized relationships underlying the research are also developed. Section 3 discusses the research methodology and introduces the sources of data. The results are then presented and analyzed in section 4 followed by a discussion of the implications for research and practice in section 5 , which also reflects on the research and discusses avenues for future research.

\section{Research Framework}

The framework underlying this research is presented in figure 1 , and is similar to the one used by Li, Ragu-Nathan, Ragu-Nathan, \& Rao (2006). The framework proposes that the adoption of sustainable 
manufacturing practices will have a direct impact on both business performance and competitive advantage. These practices will also indirectly impact business performance via competitive advantage. Because there is no universal model for operationalizing sustainable manufacturing in the literature, we choose 7 dimensions with respect to: manufacturing inputs, manufacturing processes, packaging, design for disassembly, after-use disposal, supplier management and social responsibility. We believe these dimensions represent the 'totality' of sustainability practices corresponding to the various phases of a product life cycle, i.e. practices related to the choice of raw material inputs to end-of life disposal. The 7 latent constructs are measured using indicator variables from various literature sources. The constructs of competitive advantage and business performance are already covered in several previous studies and as such no new measures are developed for this study. A more detailed discussion on the constructs used in the study is presented in the following sections.

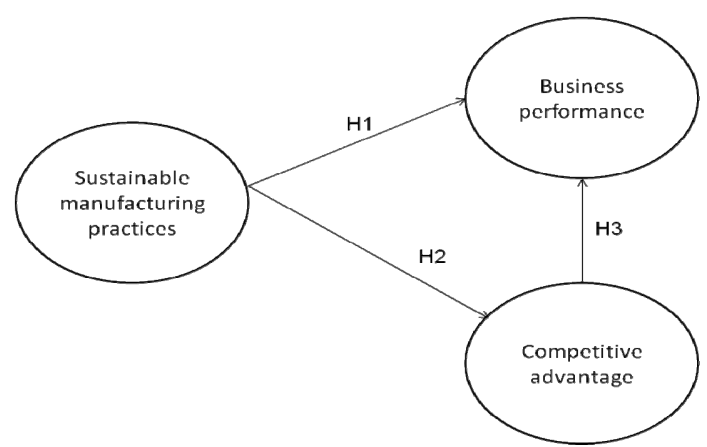

Figure 1. Research framework

\subsection{Defining Sustainable Manufacturing}

Similar to the term 'sustainable development', there is no universal definition for 'sustainable manufacturing' and over the years many different terminologies have emerged (Millar \& Russell, 2011). Johansson and Winroth (2010) explain that a number of concepts focusing on the concern for environmental issues in industrial operations have emerged in the literature, and many of these terms overlap and complement each other. Terms include: 'environmentally responsible manufacturing' (ERM) (Curkovic, 2003; Ellram, Tate, \& Carter, 2008), 'environmentally benign manufacturing' (EBM) (Bras, Isaacs, \& Overcash, 2006; Gutowski et al., 2005), 'environmentally conscious design and manufacturing' (Zhang, Kuo, Lu, \& Huang, 1997), 'green manufacturing' (Rusinko, 2007; Tan, Liu, Cao, \& Zhang, 2002), 'cleaner production' (Jackson, 2002), 'industrial ecology' (Ayres \& Ayres, 2002; Ehrenfeld, 2004) and 'industrial sustainability' (Arena et al., 2009; Jansson et al., 2000).

Sustainable manufacturing is defined by the US Department of Commerce (2009) as 'the creation of manufactured products that minimize negative environmental impacts, conserve energy and natural resources, are safe for employees, communities and consumers and are economically sound'. Gutowski et al. (2001) suggest that in order to deal with a complex issue such as sustainability, a 'systems view' of manufacturing (figure 2) which tracks the consequences of manufacturing and design decisions and takes us through raw material production, manufacturing, use and end-of-life phases should be used. Mani, Lyons, \& Sriram (2010) also point out that sustainable manufacturing requires a holistic and life cycle thinking which means going beyond the traditional focus on production sites and manufacturing processes. Therefore, it is within this framework that we choose to position our research by focusing on specific sustainable manufacturing practices at each stage of the product life cycle. 


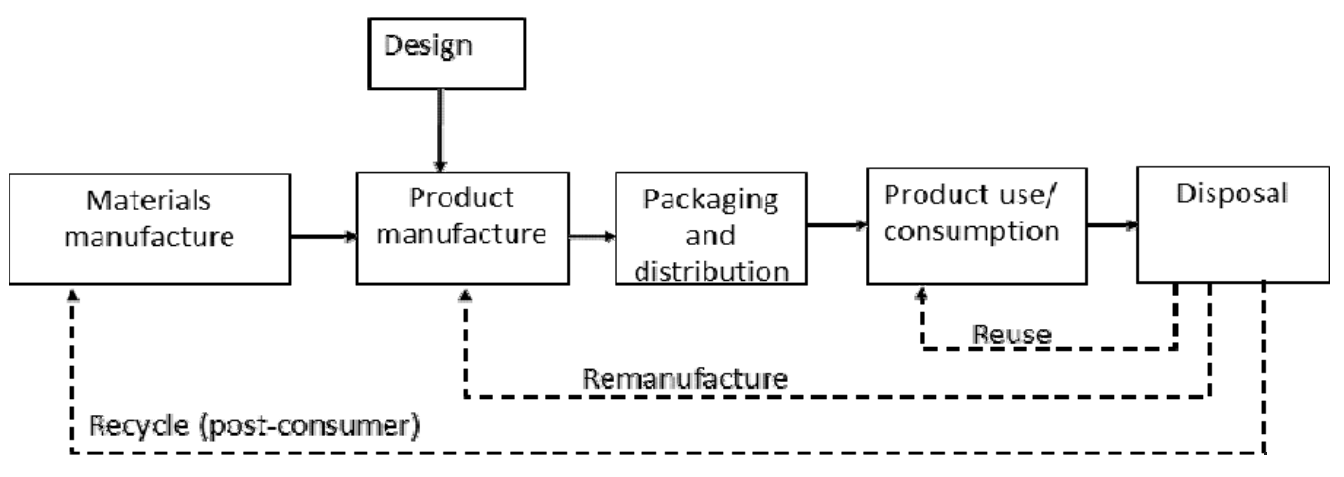

Figure 2. Life cycle view of manufacturing

Source (adapted): Gutowski et al. (2001)

\subsection{Sustainable Manufacturing Practices}

Based on the plethora of terms, it is little surprise that practices in sustainable manufacturing vary widely from company to company and from industry to industry. Much of the existing empirical research focuses on environmental management, which is often used as a proxy for environmental performance. Our research, however, proposes to study the multidimensional concept of sustainable manufacturing by giving consideration to not only environmental measures but economic and social measures-the triple-bottom line approach (Elkington, 1997) or three-pillar model (Littig \& Greißler, 2005).

Since there is little synthesis in the literature about what practices constitute sustainable manufacturing we had to define our own unique set of measures, while considering existing literature on the topic. As such, we define 7 dimensions of sustainable manufacturing practices (SMP), in tandem with the life cycle view of manufacturing. Figure 3 shows 6 of the sub-constructs we used to measure sustainable manufacturing practices. The $7^{\text {th }}$ sub-construct (not shown on the figure) is social responsibility. These sub-constructs are defined below.

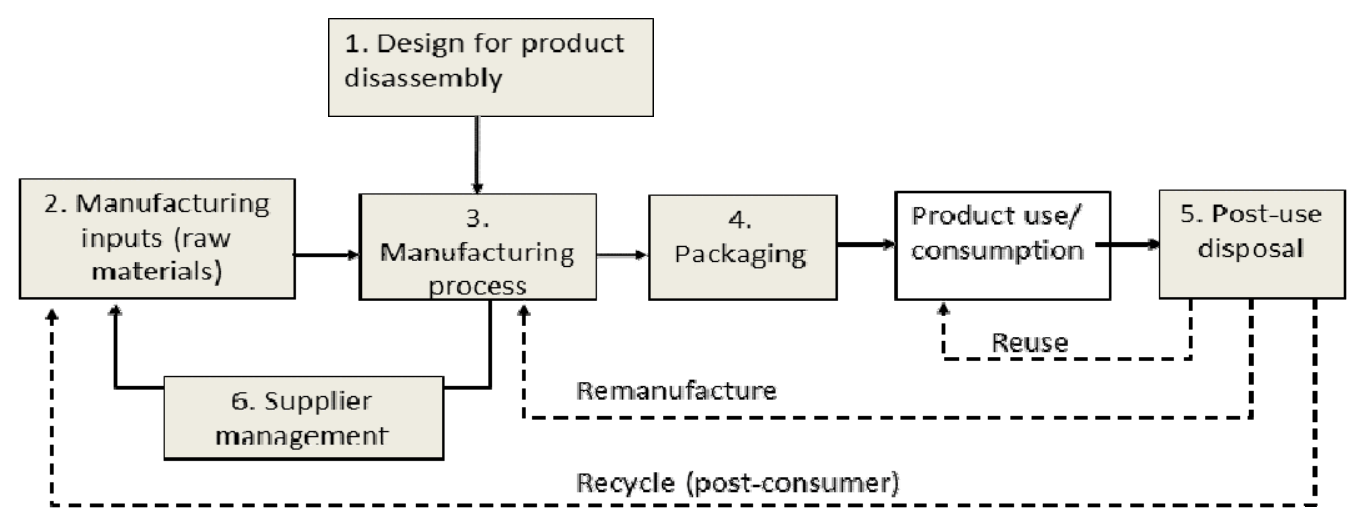

Figure 3. Measures for the construct of sustainable manufacturing practices

Design for product disassembly: Gungor and Gupta (1999) define disassembly as a systematic method for separating a product into its constituent parts, components, subassemblies or other groups. The ability to easily disassemble products that have come to the end of their useful life is important for recycling, recovery and remanufacturing, and these are determined in the product design phase. De Ron (1998) highlights practices that should have high priority in design so that a product can be disassembled easily such as the use of materials that can be recovered easily and designing with easily dividable materials.

Manufacturing inputs refer to the choice of materials and energy used in the manufacture of a product. As such, an important aspect of sustainable product design rests in the selection of materials (Arup, 2007). Making the right decisions with respect to the choice of raw materials will determine the environmental impact of the final product. Sustainability practices with regards raw materials usage include using recycled materials, 
biodegradable materials, environmentally-benign materials and the substitution of environmentally-questionable materials (Arup, 2007; Ljungberg, 2005; Rao \& Holt, 2005).

Manufacturing process (or the production phase) refers to the transformation activities that convert raw materials to finished goods. The production phase has a critical role in ensuring prevention of pollution and also that the production processes are optimized so that the generation of waste is minimized (Rao \& Holt, 2005). Some of the practices typically adopted include waste and emissions reduction, recycling and the use of renewable resources in the production processes (Arup, 2007).

Packaging refers to the practices employed for the purpose of protecting products for distribution, storage, use or sale. The use of packaging, whether it is made of glass, metal, paper or plastic contributes heavily to the solid waste stream (Rao \& Holt, 2005). Operational sustainability practices with respect to packaging include the use of returnable packaging, reduced packaging and recyclable packaging (Montabon et al., 2007).

Post-use disposal refers to those practices that enable the recovery of materials and products post-consumer use. Good disposal practices and the recovery of products at the end of their useful life are important facets of environmental sustainability. Practices and concepts that can be adopted include designing and planning for reuse, recycling, repair, regeneration and remanufacturing (Glavic \& Lukman, 2007).

Supplier management refers to practices that focus on managing the relationships between the manufacturing firm and its suppliers. Manufacturers can employ various practices and policies to help manage their supplier relationships. Practices can include selecting providers who have adopted effective environmental practices (Sarkis, 2003); integrating suppliers into the environmental management process (Walton, Handfield, \& Melnyk, 1998); and guiding suppliers to set up their own environmental programs and urging/pressing suppliers to take environmental actions (Rao \& Holt, 2005).

Social responsibility refers to practices that look at corporate 'duty' and includes how a company treats its employees and its community (Collins, Roper, \& Lawrence, 2009). Although sustainability is mostly associated with environmental sustainability, Foot and Ross (2004) point out that social practices are a key element. However, a clear theoretical concept for social sustainability is still missing (Littig \& Grießler, 2005). Social responsibility focuses on incorporating practices and policies that are cognizant of social impacts into the daily operations of businesses. Some practices include those relating to basic needs and quality of life, involvement in activities such as volunteers, integration into social networks and gender equity (Littig \& Grießler, 2005), labour practices and human rights (Lankoski, 2008); training employees in sustainability, sustainable education and outreach (Rusinko, 2007).

\subsection{Competitive Advantage}

Competitive advantage is the extent to which an organization is able to create a defensible position over its competitors ( $\mathrm{Li}$ et al., 2006). Firms create competitive advantage via their competitive capabilities or priorities, which are defined as strategic preferences or dimensions along which a company chooses to compete in the targeted market (Hayes \& Wheelwright, 1984). Numerous competitive priorities are identified in the literature. In fact, White (1996) surveyed a wide variety of literature and found several hundred measures. However, Vickery, Droge, \& Markland (1997) point out that the vast empirical literature reduces this exhaustive list to 4 or 5 core dimensions. Widely accepted competitive priorities are cost, delivery, quality and flexibility (Kathuria, 2000). Other priorities used include innovativeness (Leong, Snyder, \& Ward, 1990), environmental performance (Vachon \& Klassen, 2008) and price (Koufteros, Vonderembse, \& Doll, 2002). Krajewski and Ritzman (1987) identify cost, high performance design, consistent quality, on-time delivery and product and volume flexibility. On the basis of prior literature, we use 6 dimensions to measure competitive advantage in this study: price, quality, delivery, flexibility, product range and customization.

\subsection{Business Performance}

Business performance takes into account the organization's responsibilities towards the shareholders and has a profit maximization objective (Rappaport, 1987). Business performance includes both indicators of market performance and financial performance (Yamin, Gunasekaran, \& Mavondo, 1999). Yang, Hong, \& Modi (2011) define market performance as the degree to which an organization achieves its market valued outcomes (e.g. sales and market growth) and financial performance as the degree to which an organization achieves profit-oriented outcomes (e.g., return on investment (ROI), and return on sales (ROS)). A number of previous studies have used both financial and market performance measures such as ROI, return on asset (ROA), profit margins on sales and sales growth (for example, Claver et al., 2007; Hart \& Ahuja, 1996; Li et al., 2006; Yang et al., 2011). We use market and financial performance measures consistent with previous studies: profitability, 
ROA, ROI, sales and export growth.

\subsection{Hypotheses Development}

The research framework used in the study proposes that the adoption of sustainability practices has a direct impact on the business performance of an organization. Early on it was simply taken as a fact that pursuing environmental goals was antithetical to sound business strategy (Melnyk, Sroufe, \& Calantone, 2003) as managers held the view that adopting environmental activities and business performance were mutually exclusive. Porter (1991) challenged this view and in fact, Porter and van der Linde (1995) argued that properly designed environmental standards can trigger innovations that can enhance resource productivity, ultimately making companies more competitive. Some prior empirical work seems to suggest that firms with high environmental performance tend to be profitable (King \& Lenox, 2001). Specifically, Zeng et al. (2010) find a positive impact of cleaner production on performance measures of profitability, ROE and market share; Nakao et al. (2007) find that a firm's environmental performance has a positive impact on ROA; and Hart and Ahuja (1996) and King and Lenox (2001) find that environmental activities in terms of reduced emissions and waste prevention are associated with higher financial performance. However, it should not be taken as a foregone conclusion that sustainability practices will have a positive impact on business performance. Hahn, Figge, Pinkse, \& Preuss (2010) explain that there is not always a positive linear relationship between environmental and economic performance. This is because these practices often require organizations to make investments in human, structural and social capital, and such investments can in fact increase the cost burdens of firms, leading to reduced profitability in the short-term (Yang et al., 2011). The timing of the adoption of sustainability practices and the realisation of business performance results are also important. Hart and Ahuja (1994) point to a time lag between adoption and the realization of bottom line benefits. Although not all empirical studies have found a positive relationship, Montabon et al. (2007) point out that on the whole the literature seems to support a 'win-win' hypothesis. Albertini (2013) conducted a meta-analysis of 52 studies over a 35-year period that confirmed a positive relationship with financial performance. Therefore we hypothesize that:

H1: The adoption of sustainable manufacturing practices will be positively associated with business performance.

The adoption of sustainability practices impacts not only business performance, but also a firm's competitive advantage. They are expected to give a firm a competitive edge through competitive priorities such as price/cost, quality and innovation. Stead and Stead (1992) explain that implementing sustainability strategies can provide firms with opportunities to achieve traditional competitive advantages of cost-leadership and market differentiation. Strategies such as the elimination of waste through practices such as resource reduction and recycling can decrease cost (Porter \& van der Linde, 1995), while costs resulting from materials waste and inefficient processes can also be minimized (Schmidheiny, 1992). Prior studies have demonstrated that the adoption of various aspects of sustainable manufacturing have an impact on aspects of competitive advantage. Rao and Holt (2003) find that green supply chain leads to increased competitiveness in terms of improved quality, cost savings, improved efficiency and productivity. Rusinko (2007) finds that product stewardship practices such as the use of renewable materials and eco-friendly energy have a positive impact on innovation and product quality. On the whole, improved sustainability performance is a potential source of competitive advantage, leading to more efficient processes, improvements in productivity and new market opportunities (Wagner \& Schlategger, 2003). These arguments lead us to hypothesize that:

H2: The adoption of sustainable manufacturing practices will be positively associated with competitive advantage.

Having a competitive advantage generally suggests that an organization can have one or more of the following capabilities when compared to its competitors: lower prices, higher quality, higher dependability, and shorter delivery time (Li et al., 2006). According to Mentzer, Min, \& Zacharia (2000), these capabilities will, in turn, enhance the organization's overall performance. Therefore, as the competitiveness of a firm is improved, this will be reflected in its business performance. Hence, we propose a positive relationship between competitive advantage and business performance and hypothesize that:

H3: Competitive advantage will be positively associated with business performance.

These 3 hypotheses together support our theorized model presented in figure 1.

\section{Method}

\subsection{Survey Instrument and Data Collection}

A survey-based approach was adopted in order to test our conceptual research model. Our study examines the 
sustainability practices of manufacturing firms in the five Caribbean countries accounting for the majority of manufacturing in the region: Trinidad and Tobago, Jamaica, Guyana, St Lucia and Barbados. The questionnaire was administered to different industrial sectors in the manufacturing industry. The final version of the questionnaire was sent out in two stages. First, the questionnaire and a cover letter explaining the purpose of the study were sent to the respective manufacturing associations in each of the 5 countries. The associations then invited their members to participate in the web-based survey that was posted on the associations' websites. After 3 months, only 10 companies had completed the questionnaire. In order to increase the dataset, we decided on a second approach. We asked each manufacturing association to organize a seminar on sustainable manufacturing and invite their members to attend. The manufacturing companies in attendance were informed beforehand that they would be invited to complete the questionnaire at the start of the seminar. Sixty-six (66) completed questionnaires were collected at the seminars.

\subsection{Measures}

Three latent constructs were used to test the hypothesized relationships: sustainable manufacturing practices (SMP), business performance (BP) and competitive advantage (CA). The BP and CA constructs were perceptual measures of financial performance and competitiveness, respectively, whereby respondents rated their organization relative to their competitors. The BP and CA constructs were measured using 5 and 6 items, respectively. The construct of SMP was operationalized using the 7 dimensions shown in figure 3 , and 36 specific practices (see Supporting Information) which were based on sustainability practices in the literature and augmented by measures deemed relevant to the Caribbean region. The number of practices used in similar studies varies widely, so we undertook extensive discussions with Caribbean manufacturers as a means of enhancing the content validity of the SMP construct. Practices were discussed with 9 Caribbean manufacturers and based on their feedback redundant, ambiguous and irrelevant practices were modified or removed prior to administering the final questionnaire.

The constructs of competitive advantage (CA) and business performance (BP) were evaluated on a Likert's five-point scale. Since the study sought to analyze the adoption of sustainable manufacturing practices a binary scale was used: 0 if the respondent did not adopt the particular practice and 1 if practice was adopted. Similar to Stinchfield, Li, \& Du (2009) we added the value for each response. For example, respondent \#1 responses for the total number of sustainable manufacturing practices adopted was 19. Overall, the total number of sustainable manufacturing practices ranged from 0 to 33, with a mean of 16.34 and standard deviation of 7.539.

\subsection{Sample and Respondent Profile}

Seventy-six (76) manufacturing firms from 5 Caribbean countries participated in the study: Trinidad and Tobago (38\% of respondents); Barbados and Jamaica (22\% each); and Guyana and St. Lucia ( $9 \%$ each). Almost $90 \%$ of the respondents occupied senior positions in their organizations such as CEO, director, production, operations or plant manager. We can therefore assume a certain level of credibility with the responses given. More than $80 \%$ of the companies in our study can be regarded as mature organizations, having been operating for more than 10 years. The majority $(80 \%)$ of the respondents earn less than $40 \%$ of their sales from exports. A breakdown of the industry sectors and other descriptive are presented in Appendix A.

\section{Results}

The conceptual model shown was tested using the partial least squares structural equation modeling (PLS-SEM) technique (Wold, 1985). PLS-SEM was used because of its suitability to analyze data from a small sample size and in order to avoid the multi-collinearity and measurement errors (Koh, Demirbag, Bayraktar, Tatoglu, \& Zaim, 2007; Chen, 2010). A strong rule of thumb for sample size is the larger of either ten times the scale with the largest number of formative indicators or ten times the largest number of structural paths directed at a particular construct in the structural model (Chin, 2000). Since our constructs were modelled to be reflective the latter heuristic was used. The minimum sample size requirement is therefore $20(10 \text { times } 2)^{2}$. First we tested the measurement model to establish validity and reliability and then we tested the structural relationships. We used SmartPLS 2.0 (Ringle, Wende, \& Will, 2005) to verify our hypotheses.

\subsection{Results for the Measurement Model}

The adequacy of the measurement model was addressed by evaluating the reliability of individual items expected to measure the same construct and the discriminant validity between the constructs (White, Varadarajan, \& Dacin, 2003).

\subsubsection{Convergent Validity}

Convergent validity refers to the consistency that multiple items exhibit in measuring the same construct. In 
other words, we should be able to show that measures that should be related are in reality related (Trochim, 2002). The intercorrelations, means and standard deviations for the measures used in the study are shown in table 1. For the sustainable manufacturing construct, the indicators are designed to measure specific dimensions of sustainable manufacturing practices and are not required to be related, and as such can be independent of each other. For the companies in our study, however, several of the indicators are positively and significantly correlated with each other. The measures that are not significantly correlated can be interpreted as being independent of each other, i.e. their correlation coefficients are not statistically different from 0 . For example, the adoption of sustainability practices with respect to design for disassembly is not necessarily accompanied by the adoption of practices with respect to manufacturing inputs (the correlation coefficient -0.05 was not statistically significant). The average variance extracted (AVE) and composite reliability (CR) results from SmartPLS are also adequate indicators of the convergent validity of measurements (Bagozzi \& Yi, 1988). The AVE and CR for the constructs used in our study are shown in table 2 . All 3 constructs have values higher than the 0.5 for AVE and 0.7 for CR suggested as acceptable convergent validity by Chin (1998).

\subsubsection{Discriminant Validity}

Discriminant validity needs to show that measures that should not be related are in reality not related (Trochim, 2002). In the measurement of discriminant validity the correlations between different constructs should be lower when compared with their own extracted variance explanations (Chen, 2010). Chin (2000) points out that all AVE measures should be larger than the square of the correlations. Alternatively, the square root of the AVE of a construct should be higher than its correlation coefficient with other constructs (Chin, 1998). Based on this, table 2 shows adequate discriminant validity for all three constructs. Another method for evaluating discriminant validity involves looking at the cross-loadings of the constructs. Factor loadings belonging to the same construct should be higher than those of different constructs (Chin, 1998). The cross-loadings of the constructs are presented in Appendix B. It shows that no item loaded on to any other construct more strongly than it did on its associated construct.

Table 1. Means, standard deviations and inter-construct correlations

\begin{tabular}{|c|c|c|c|c|c|c|c|c|c|}
\hline Variables & Mean & SD & 1 & 2 & 3 & 4 & 5 & 6 & 7 \\
\hline \multicolumn{10}{|c|}{ a. SM practices } \\
\hline SMP1 & 2.64 & 1.74 & 1 & & & & & & \\
\hline SMP2 & 4.08 & 2.53 & $.381^{* *}$ & 1 & & & & & \\
\hline SMP3 & 1.07 & 1.20 & $.247^{*}$ & $.439^{* *}$ & 1 & & & & \\
\hline SMP4 & 0.45 & 0.75 & -.05 & $.420^{* *}$ & .192 & 1 & & & \\
\hline SMP5 & 1.07 & 1.24 & $.428^{* *}$ & $.579^{* *}$ & $.339^{* *}$ & $.263^{*}$ & 1 & & \\
\hline SMP6 & 0.65 & 0.93 & $.372^{* *}$ & $.333^{* *}$ & .138 & .096 & $.315^{* *}$ & 1 & \\
\hline SMP7 & 6.01 & 2.68 & $.344^{* *}$ & $.470^{* *}$ & $.311^{* *}$ & .129 & $.323^{* *}$ & $.375^{* *}$ & 1 \\
\hline \multicolumn{10}{|c|}{ b. Business performance } \\
\hline $\mathrm{BP} 1$ & 2.13 & 1.77 & 1 & & & & & & \\
\hline BP2 & 2.08 & 1.82 & $.877^{* *}$ & 1 & & & & & \\
\hline BP3 & 2.00 & 1.83 & $.843^{* *}$ & $.897^{* *}$ & 1 & & & & \\
\hline BP4 & 2.17 & 1.84 & $.753^{* *}$ & $.832^{* *}$ & $.800^{* *}$ & 1 & & & \\
\hline BP5 & 1.78 & 1.68 & $.733^{* *}$ & $.707^{* *}$ & $.767^{* *}$ & $.709^{* *}$ & 1 & & \\
\hline \multicolumn{10}{|c|}{ c. Competitive advantage } \\
\hline CA1 & 2.36 & 2.07 & 1 & & & & & & \\
\hline $\mathrm{CA} 2$ & 2.47 & 2.15 & $.848^{* *}$ & 1 & & & & & \\
\hline CA3 & 2.46 & 2.18 & $.811^{* *}$ & $.796^{* *}$ & 1 & & & & \\
\hline CA4 & 1.84 & 1.85 & $.803^{* *}$ & $.763^{* *}$ & $.700^{* *}$ & 1 & & & \\
\hline CA5 & 1.84 & 1.91 & $.714^{* *}$ & $.753^{* *}$ & $.595^{* *}$ & $.656^{* *}$ & 1 & & \\
\hline CA6 & 1.78 & 1.80 & $.736^{* *}$ & $.638^{* *}$ & $.671^{* *}$ & $.665^{* *}$ & $.516^{* *}$ & 1 & \\
\hline
\end{tabular}


Table 2. AVE, CR and reliability results for the constructs

\begin{tabular}{|c|c|c|c|c|c|c|}
\hline \multirow{2}{*}{ Construct } & \multirow{2}{*}{$\begin{array}{l}\text { Average variance } \\
\text { extracted } \\
\text { (AVE) }\end{array}$} & \multirow{2}{*}{$\begin{array}{l}\text { Composite reliability } \\
\text { (CR) }\end{array}$} & \multicolumn{3}{|c|}{ Correlation coefficient } & \multirow{2}{*}{$\begin{array}{l}\text { Reliability } \\
\text { (Cronbach's Alpha) }\end{array}$} \\
\hline & & & BP & $\mathrm{CA}$ & SMP & \\
\hline$\overline{\mathrm{BP}}$ & .819 & .969 & $.905^{*}$ & & & .963 \\
\hline $\mathrm{CA}$ & .733 & .950 & .697 & $.856^{*}$ & & .939 \\
\hline SMP & .512 & .821 & -.183 & .002 & $.716^{*}$ & .756 \\
\hline
\end{tabular}

Note. ${ }^{*}$ - square root of the average variance extracted (AVE) for construct

\subsubsection{Reliability}

Cronbach's Alpha was used to assess the reliability of the three constructs. The results in table 2 show that the reliability values are all greater than 0.7 which is generally acceptable for a construct (Nunnally, 1978).

\subsection{Results for the Structural Model}

Given that the measurement model showed sufficient convergent and discriminant validity measures, the hypothesized relationships among the constructs sustainable manufacturing practices, competitive advantage and business performance were then tested. Figure 4 shows the path diagram results and the bootstrapped $t$-values are shown in table 3.

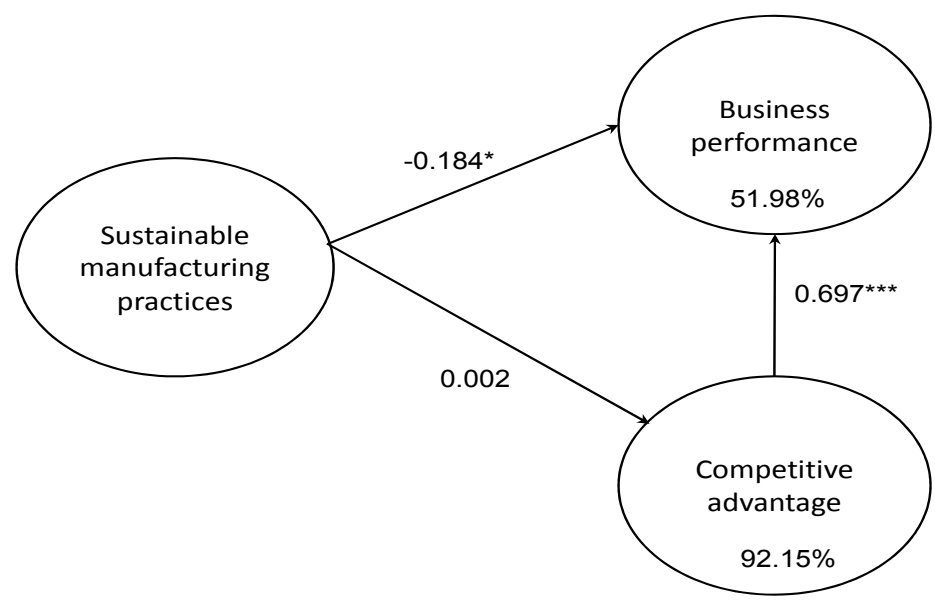

Figure 4. PLS results for hypothesized model

Note. ${ }^{*}: \mathrm{t}>|1.96|, \mathrm{p}<0.05 ; * *: \mathrm{t}>|2.58|, \mathrm{p}<0.01 ; * * * \mathrm{t}>|3.29|, \mathrm{p}<0.001$

Table 3. Results of path analyses and hypotheses tests

\begin{tabular}{llll}
\hline Path (from-to) & Coefficient & T-value & Support \\
\hline H1: Sustainable manufacturing $\rightarrow$ Business performance & -0.184 & 1.994 & H1: Not supported \\
H2: Sustainable manufacturing $\rightarrow$ Competitive advantage & 0.002 & 0.2699 & H2: Not supported \\
H3: Competitive advantage $\rightarrow$ Business performance & 0.697 & 12.512 & H3: Supported \\
\hline
\end{tabular}

\subsubsection{Sustainable Manufacturing Practices and Business Performance}

Figure 4 shows that the adoption of sustainable manufacturing practices is statistically significantly associated with business performance $(p<0.05)$. However, the sign on the coefficient shows that this relationship is negatively correlated, and therefore hypothesis 1 is not supported. These findings imply that high levels of adoption of sustainability practices result in low levels of business performance. We point to two possible reasons for our results. Firstly, it is possible that at the time of this study, adopting sustainability practices is more transactional and cost related and the particular practices adopted by the firms require some upfront investment, thereby negatively impacting the bottom line. However, there appears to be a time-lag within which firms will realize benefits. Hart and Ahuja (1996) found that environmentally-conscious business practices took up to 2 years to improve profitability measures of return on sales (ROS), return on assets (ROA and return on 
equity (ROE). The manufacturing firms in this study are in fact in their infancy in adopting sustainability practices (Millar \& Russell, 2011). Given this and the suggestion that benefits from product and process optimization may take some time to be realized, it is probably still too early for the firms in our study to have started to reap the benefits in terms of financial and market performance. Secondly, the majority of the sustainability practices in our study are process-driven as opposed to market-driven strategies. Stead and Stead (1992) explain that process-driven sustainability strategies are significantly more likely to have negative impacts on revenues and require significant financial investments to implement.

\subsubsection{Sustainable Manufacturing Practices and Competitive Advantage}

Figure 4 shows that the adoption of sustainable manufacturing practices has no significant relationship with competitive advantage $(\mathrm{p}>0.1)$ and therefore hypothesis 2 is not supported. Our findings suggest that the firms in our study may not be using sustainability to gain competitive advantage. This result is not surprising as Millar and Russell (2011) show that sustainable manufacturing practices are not widely adopted in the Caribbean. Caribbean manufacturers are therefore not entirely aware of the potential value of sustainability and as such it is not presently being exploited as a source of competitive advantage. We believe another possible explanation for the results has to do with consumer behavior. Caribbean consumers are not yet using sustainability as a principal factor in their purchasing decisions. Instead, cost and quality play a much greater influencing role (Millar \& Russell, 2011).

\subsubsection{Competitive Advantage and Business Performance}

The relationship between competitive advantage and business performance is strongly statistically significant ( $\mathrm{p}$ $<0.001$ ) and positive (figure 4). This result provides support for hypothesis 3, suggesting that firms with high levels of competitive advantage will also have better business performance. Our conceptual model hypothesized that sustainability practices would indirectly impact business performance via competitive advantage, but our results show no significant relationship between the adoption of sustainability practices and competitive advantage and a negative significant relationship with business performance. Since there is a positive significant relationship between competitive advantage and business performance, our results seem to suggest that any improvements in business performance resulting from improved competitive advantage is not as a direct result of adopting sustainability practices but rather would have to be attributed to other factors not considered in this research, such as better quality and lower costs.

The level of adoption of sustainability practices may be influenced by factors such as firm size, annual turnover and other contextual factors. We compared different levels of adoption of sustainability practices, which we clustered as low versus high adopters, based on the total number of practices adopted. Using chi-squared statistic and $\mathrm{p}<0.05$ we test for relationships between these 2 groups using variables such as firm size (number of employees as a proxy), age of firm and annual sales/turnover. Our results show no significant differences in the adoption of sustainability practices based on firm size, i.e. no difference in levels of adoption between SMEs and large firms ${ }^{3}$. There is also no significant difference in the adoption of sustainability practices based on the age of the firm. While younger firms could potentially use sustainability as a "game changer" and as a means of gaining market advantage, this is currently not happening. The chi-squared tests also show no significant relationship between annual sales and the adoption of sustainability practices, which is not surprising as Caribbean consumers are yet to place any significant value on sustainability and reward those companies adopting such practices.

\section{Discussion}

In this study we have empirically tested the relationships among the adoption of sustainable manufacturing practices, business performance and competitive advantage for Caribbean manufacturing firms. We find a significant negative relationship between sustainability practices and business performance and no significant relationship between sustainability practices and competitive advantage. These results imply that adopting sustainable manufacturing practices may not lead to better business performance and improved competitiveness.

So the debate continues. Does it really pay to be green? Based on our results, should Caribbean manufacturers abandon the idea of sustainable manufacturing as it appears to be an apparent financial burden with little opportunity for enhanced competitiveness and improved performance? Finding similar results, Cordeiro and Sarkis (1997) caution that although the results are prima facie discouraging for companies seeking to be environmentally proactive, the results do not necessarily indicate that these firms lose money over the long-term. Moreover, the nature of investments required and expected financial returns differ from strategy to strategy, industry to industry, and firm to firm and as such although managers should pursue sustainability strategy implementation with some vigor, they must base their choices of particular strategies on sound analysis of their 
respective situations (Stead \& Stead, 1992). This means managers should invest in environmental expenditures wisely (First \& Khetriwal, 2010). We can conclude that more research is required in order to gather more evidence to resolve the paradox of whether it really pays for Caribbean manufacturers to be green. However, what is clear from our study is that sustainability, at this point in time, is not a key driver of competitiveness for these firms. Presently, there is a general lack of environmental regulation across the Caribbean region and companies are under little obligation to engage in sustainability practices. Our results may seem to encourage a delay in investing in sustainability practices as they do not appear to deliver benefits in the short-term. However, manufacturers may be willing to adopt these practices, if properly incentivized. We believe governments can help by providing financial incentives in the form of tax breaks, green schemes, low-interest loans and even consider changes in the tariff structure to encourage the use of 'green' suppliers of raw materials. In this way manufacturers are encouraged to improve their levels of adoption, without negatively impacting their financial position.

Another strategy recommendation is for manufacturers to focus on the 'low hanging fruits' first. If manufacturers adopt sustainability practices that require very little or no financial investment, they may be able to reap the rewards without paying the price. Firms in the early stages of adopting sustainability practices should put their emphasis on improving resource productivity, which would have the secondary effect of lowering manufacturing costs. Lowering manufacturing costs will support cost competitiveness and can lead to better business performance.

Small- and medium-sized companies often lack the financial and human resources to invest in sustainability. As such, regional manufacturing associations can act as major advocates and partners and provide the requisite training and skills development in sustainability. They can also partner with regional academic institutions and conduct workshops and seminars on sustainable manufacturing. Finally, governments can help to offset costs by subsidizing the cost of auditors and consultants to assist manufacturers in identifying those 'low hanging' sustainability practices that can give the most benefit with the least investment. Governments in the Caribbean see enhancing the export potential of the manufacturing industry as a key economic imperative. As international markets increasingly demand greener products, it is in their best interest to develop policy mechanisms and instruments that help to move the industry towards greater adoption of sustainability practices.

Our results reveal that Caribbean manufacturers are not currently using sustainability as a competitive strategy. However, as consumers become more environmentally savvy sustainability could become a competitive differentiator and a factor in their purchasing decisions. Caribbean manufacturers should therefore invest in branding and marketing as a way of influencing consumer behavior while positioning themselves to meet the needs of consumers who will eventually begin to demand greener products.

Finally, the results of our study have implications for other developing regions whose manufacturers may be at similar stages of growth and may be considering whether it actually pays to be 'green'. Even though our results may seem to discourage investing until clear evidence of short-term benefits are more widespread, this may not be a good strategy, for since it is likely that benefits accrue in the long-term, by the time they become fully observable, manufacturers in developing regions will have much catching up to do. Consequently, we would encourage manufacturers in these regions to bet on the long-term view in order to ensure a fighting chance at competing in an environment where sustainability is increasingly becoming a competitive differentiator.

The link between the adoption of sustainable manufacturing practices, business performance and competitiveness cannot be established with certainty based on a single study. Although we used a comprehensive set of measures and a triple bottom line approach to defining and measuring sustainability we are aware of the limitations of the empirical research. First, the study was limited to only a small number of firms across several industrial sectors. This means that cross-sectoral comparisons were not possible. A more comprehensive study that focuses on several firms in the same industrial sector could help identify whether there are some sustainability practices that are sector-specific that are more likely to drive business performance and competitive advantage. Second, we note that the data was collected from a single respondent in each company, and as such the possibility of response bias. Third, quantitative financial and market data would have been preferred, but due to its unavailability (as many of the firms are private corporations) all data were measured in terms of self-perceptions of the respondents.

Given that no previous study has been done in the Caribbean region we believe this research is timely and significant and is a good starting point in the discussion of whether it really pays for Caribbean manufacturers to be green. As a direction of future study it would be interesting to repeat the study after some time has elapsed when sustainability would more likely have become an imperative not an option, to see if Caribbean 
manufacturing firms have begun to employ sustainability as a source of competitive advantage and a means of improving financial and market performance. Finally, a longitudinal study involving a set of manufacturers evolving over the various stages of maturity with sustainable manufacturing practices will help to illuminate how business performance and competitive advantage improve over time.

\section{Acknowledgments}

The research was funded in part by the National Science and Engineering Research Council of Canada, grant no. OGP0089663. The following manufacturing associations were instrumental in helping us to gain access to their members: The Jamaica Manufacturers' Association (JMA), The Barbados Manufacturers' Association (BMA), The Trinidad and Tobago Manufacturers' Association (TTMA), The Saint Lucia Manufacturers' Association (SLMA) and The Guyana Manufacturing and Services Association (GMSA).

\section{References}

Albertini, E. (2013). Does environment management improve financial performance? A meta-analysis review. Organization and Environment, 26(4), 431-457. http://dx.doi.org/10.1177/1086026613510301

Aragón-Correa, J. A., Hurtado-Torres, N., Sharma, S., \& García-Morales, V. J. (2008). Environmental strategy and performance in small firms: A resource-based perspective. Journal of Environmental Management, 86, 88-103. http://dx.doi.org/10.1016/j.jenvman.2006.11.022

Arena, M., Ciceri, N. D., Terzi, S., Bengo, I., Azzone, G., \& Garetti, M. (2009). A state-of-the-art of industrial sustainability: definitions, tools and metrics. Int. J. Product Lifecycle Management, 4(1/2/3), 207-251. http://dx.doi.org/10.1504/IJPLM.2009.031674

Arup. (2007). Sustainable manufacturing: A study into UK manufacturers' perceptions. Ove Arup and Partners Limited.

Ayres, R. U., \& Ayres, L. W. (Eds.). 2002. A Handbook of Industrial Ecology. UK: Edward Elgar Publishing Limited.

Bagozzi, R. P., \&Yi, Y. (1988). On the evaluation of structural equation models. Journal of the Academy of Marketing Science, 16(1), 74-94. http://dx.doi.org/10.1007/BF02723327

Bras, B., Isaacs, J., \& Overcash, M. (2006). Environmentally benign manufacturing—a workshop report. Journal of Cleaner Production, 14(5), 527-535. http://dx.doi.org/10.1016/j.jclepro.2005.03.019

CEC (Commission of European Communities). (1996). Commission recommendation of 3 April 1996 concerning the definition of small and medium-sized enterprises. Official Journal L 107, 30/04/1996: 0004-0009 (Document 396X0280).

Chen, H. J. (2010). Linking employees' e-learning system to their use to their overall job outcomes: an empirical study based on the IS success model. Computers and Education, 55, 1628-1639. http://dx.doi.org/10.1016/j.compedu.2010.07.005

Chin, W. W. (1998). Issues and opinion on structural equation modeling. MIS Quarterly, 22(1), vii-xvi.

Chin, W. W. (2000). Frequently Asked Questions - Partial Least Squares \& PLS-Graph. Home Page. Retrieved from http://disc-nt.cba.uh.edu/chin/plsfaq.htm.

Claver, E., López, M. D., Molina, J. F., \&Tarí, J. J. (2007). Environmental management and firm performance: A case study. Journal of Environmental Management, 84, 606-619. http://dx.doi.org/10.1016/j.jenvman.2006.09.012

Collins, E., Roper, J., \& Lawrence, S. (2009). Sustainability practices: trends in New Zealand businesses. Business Strategy and the Environment, 18, 1-16.

Cordeiro, J. J., \& Sarkis, J. (1997). Environmental proactivism and firm performance: evidence from security analyst earnings forecast. Business Strategy and the Environment, 6(2), 104-114. http://dx.doi.org/10.1002/(SICI)1099-0836(199705)6:2<104::AID-BSE102>3.0.CO;2-T

Curkovic, S. (2003). Environmentally responsible manufacturing: the development and validation of a measurement model. European Journal of Operational Research, 146(1), 130-155. http://dx.doi.org/10.1016/S0377-2217(02)00182-0

De Ron, A. J. (1998). Sustainable production: The ultimate result of a continuous improvement. Int. Journal of Production Economics, 56-57, 99-110. http://dx.doi.org/10.1016/S0925-5273(98)00005-X

Ehrenfeld, J. (2004). Industrial ecology: a new field or only a metaphor? Journal of Cleaner Production, 12, 
825-831. http://dx.doi.org/10.1016/j.jclepro.2004.02.003

Elkington, J. (1997). Cannibals with forks: the triple bottom line of $21^{\text {st }}$ century business. Oxford: Capstone Publishing.

Ellram, L., Tate, W., \& Carter, C. R. (2008). Applying 3DCE to environmentally responsible manufacturing practices. Journal of Cleaner Production, 16(15), 1620-1631. http://dx.doi.org/10.1016/j.jclepro.2008.04.017

First, I., \& Khetriwal, D. S. (2010). Exploring the relationship between environmental orientation and brand value: is there fire or only smoke? Business Strategy and the Environment, 19, 90-103.

Foot, D. K., \& Ross, S. (2004). Social Sustainability. In C. Galea (Ed.), Teaching Business Sustainability Volume 1: From theory to practice (pp. 107-125). Sheffield: Greenleaf Publishing Limited.

Glavic, P., \& Lukman, R. (2007). Review of sustainability terms and their definitions. Journal of Cleaner Production, 15, 1875-1885. http://dx.doi.org/10.1016/j.jclepro.2006.12.006

Gombauldt, M., \& Versteege, S. (1999). Cleaner production in SMEs through a partnership with (local) authorities: success from the Netherlands. Journal of Cleaner Production, 7(4), 249-261. http://dx.doi.org/10.1016/S0959-6526(99)00084-0

Gungor, A., \& Gupta, S. (1999). Issues in environmentally conscious manufacturing and product recovery: a survey. Computers and Industrial Engineering, 36, 811-853. http://dx.doi.org/10.1016/S0360-8352(99)00167-9

Gutowski, T. G., Murphy, C. F., Allen, D. T., Bauer, D. J., Bras, B., Piwonka, T. S., ... Wolff, E. E. (2001). Environmentally benign manufacturing WTEC Panel report. International Technology Research Institute.

Gutowski, T., Murphy, C., Allen, D., Bauer, D., Bras, B., Piwonka, T., ... Wolff, E. (2005). Environmentally benign manufacturing: observations from Japan, Europe and the United States. Journal of Cleaner Production, 13(1), 1-17. http://dx.doi.org/10.1016/j.jclepro.2003.10.004

Hahn, T., Figge, F., Pinkse, J., \& Preuss, L. (2010). Trade-offs in corporate sustainability: You can't have your cake and eat it. Business Strategy and the Environment, 19(4), 217-229.

Handfield, R. B., Walton, S. V., Seegers, L. K., \& Melnyk, S. A. (1997). 'Green' value chain practices in the furniture industry. Journal of Operations Management, 15(4), 293-315. http://dx.doi.org/10.1016/S0272-6963(97)00004-1

Hart, S. L., \& Ahuja, G. (1996). Does it pay to be green? An empirical examination of the relationship between emission reduction and firm performance. Business Strategy and the Environment, 5, 30-37. http://dx.doi.org/10.1002/(SICI)1099-0836(199603)5:1<30::AID-BSE38>3.0.CO;2-Q

Hayes, R. H., \& Wheelwright, S. C. (1984). Restoring our competitive edge: Competing through manufacturing. New York: Wiley.

Henri, J. F., \& Journeault, M. (2008). Environmental performance indicators: an empirical study of Canadian manufacturing firms. Journal of Environmental Management, 87, 165-176. http://dx.doi.org/10.1016/j.jenvman.2007.01.009

Jackson, T. (2002). Industrial ecology and cleaner production. In R. U. Ayres, \& L. W. Ayres (Eds.), A Handbook of Industrial Ecology (pp. 36-43). UK: Edward Elgar Publishing Limited.

Jansson, P. M., Gregory, M. J., Barlow, C., Phaal, R., Farrukh, C. J. P., Probert, D. R., \& So, V. (2000). Industrial sustainability $-A$ review of $U K$ and International research and capabilities. University of Cambridge, Cambridge.

Johansson, G., \& Winroth, M. (2010). Introducing environmental concerns in manufacturing strategies: Implications for the decision criteria. Management Research Review, 33(9), 877-899. http://dx.doi.org/10.1108/01409171011070305

Kathuria, R. (2000). Competitive priorities and managerial performance: a taxonomy of small manufacturers. Journal of Operations Management, 18, 627-641. http://dx.doi.org/10.1016/S0272-6963(00)00042-5

King, A. A., \& Lenox, M. J. (2001). Does it really pay to be green? An empirical study of firm environmental and financial performance. Journal of Industrial Ecology, 5(1), 105-116. http://dx.doi.org/10.1162/108819801753358526

Klassen, R. D., \& McLaughlin, C. P. (1996). The impact of environmental management on firm performance. 
Management Science, 42(8), 1199-1214. http://dx.doi.org/10.1287/mnsc.42.8.1199

Klassen, R. D., \& Whybark, D. C. (1999). The impact of environmental technologies on manufacturing performance. Academy of Management Journal, 42(6), 599-615. http://dx.doi.org/10.2307/256982

Koh, S. C. L., Demirbag, M., Bayraktar, E., Tatoglu, E., \& Zaim, S. (2007). The impact of supply chain management practices on performance of SMEs. Industrial Management and Data Systems, 107(1), 103-124. http://dx.doi.org/10.1108/02635570710719089

Koufteros, X. A., Vonderembse, M. A., Doll, W. J. (2002). Examining the competitive capabilities of $\begin{array}{llll}\text { manufacturing firms. } & \text { Structural } & \text { Equation }\end{array}$ http://dx.doi.org/10.1207/S15328007SEM0902_6

Krajewski, L. J., \& Ritzman, L. P. (1987). Operations management, strategy and analysis. Boston: Addison-Wesley Publishing Company.

Lankoski, L. (2008). Corporate responsibility activities and economic performance: a theory of why and how they are connected. Business Strategy and the Environment, 17, 536-547. http://dx.doi.org/10.1002/bse.582

Leong, G. K., Snyder, D. L., \& Ward, P. T. (1990). Research in the process and content of manufacturing strategy. Omega, 18, 109-122. http://dx.doi.org/10.1016/0305-0483(90)90058-H

Li, S., Ragu-Nathan, B., Ragu-Nathan, T. S., \& Rao, S. S. (2006). The impact of supply chain management practices on competitive advantage and organizational performance. Omega, 34, 107-124. http://dx.doi.org/10.1016/j.omega.2004.08.002

Littig, B., \& Grießler, E. (2005). Social sustainability: a catchword between political pragmatism and social theory. International Journal of Sustainable Development, 8(1/2), 65-79. http://dx.doi.org/10.1504/IJSD.2005.007375

Ljungberg, L. Y. (2005). Materials selection and design for development of sustainable products. Materials Design, 28(2), 466-479. http://dx.doi.org/10.1016/j.matdes.2005.09.006

Mani, M., Lyons, K., \& Sriram, R. (2010). Developing a sustainability manufacturing maturity model. Proceedings from IMS Summer School on Sustainable Manufacturing, 311-321.

Melnyk, S. A., Sroufe, R. P., \& Calantone, R. (2003). Assessing the impact of environmental management systems on corporate and environmental performance. Journal of Operations Management, 21, 329-351. http://dx.doi.org/10.1016/S0272-6963(02)00109-2

Mentzer, J. T., Min, S., \& Zacharia, Z. G. (2000). The nature of inter-firm partnering in supply chain management. Journal of Retailing, 76(4), 549-568. http://dx.doi.org/10.1016/S0022-4359(00)00040-3

Millar, H. H, \& Russell, S. N. (2011). The adoption of sustainable manufacturing practices in the Caribbean. Business Strategy and the Environment, 20, 512-526. http://dx.doi.org/10.1002/bse.707

Montabon, F., Sroufe, R., \& Narasimhan, R. (2007). An examination of corporate reporting, environmental management practices and firm performance. Journal of Operations Management, 25(5), 998-1014. http://dx.doi.org/10.1016/j.jom.2006.10.003

Nakao, Y., Amano, A., Matsumura, K., Genba, K., \& Nakano, M. (2007). Environmental performance and financial performance: an empirical analysis of Japanese companies. Business Strategy and the Environment, 16, 106-118. http://dx.doi.org/10.1002/bse.476

Nunnally, J. (1978). Psychometric theory. New York: McGraw-Hill.

Porter, M. E. (1991). America's green strategy. Scientific American, 264(4), 168. http://dx.doi.org/10.1038/scientificamerican0491-168

Porter, M. E., \& Van der Linde, C. (1995). Green and competitive: ending the stalemate. Harvard Business Review, 73(5), 120-134.

Rao, P., \& Holt, D. (2005). Do green supply chains lead to competitiveness and economic performance? International Journal of Operations and Production Management, 25(9/10), 898-916.

Rappaport, A. (1987). Stock market signals to managers. Harvard Business Review, 65(6), 63-76.

Ringle, C. M., Wende, S., \& Will, S. (2005). SmartPLS 2.0 (M3) Beta. Hamburg. http://www.smartpls.de.

Rusinko, C. A. (2007). Green manufacturing: an evaluation of environmentally sustainable manufacturing practices and their impact on competitive outcomes. IEEE Transactions on Engineering Management, 54(3), 
445-454. http://dx.doi.org/10.1109/TEM.2007.900806

Russo, M. V., \& Fouts, P. A. (1997). A resource-based perspective on corporate environmental performance and profitability. Academy of Management Journal, 40(3), 534-559. http://dx.doi.org/10.2307/257052

Sarkis, J. (2003). A strategic decision framework for green supply chain management. Journal of Cleaner Production, 11, 397-409. http://dx.doi.org/10.1016/S0959-6526(02)00062-8

Schaltegger, S., \& Synnestvedt, T. (2002). The link between 'green' and economic success: environmental management as the crucial trigger between environmental and economic performance. Journal of Environmental Management, 65, 339-346. http://dx.doi.org/10.1006/jema.2002.0555

Schmidheiny, S. (1992). Changing course: a global business perspective on development and the environment. Cambridge, MA: MIT Press.

Shahbazpour, M., \& Seidel, R. (2006). Using sustainability for competitive advantage. LCE $2006,13^{\text {th }}$ CIRP International Conference on Life Cycle Engineering, 31 May - 2 Jun, 2006. Leuven, Belgium.

Stead, W. E., \& Stead, J. G. (1992). Management for a small planet: Strategic decision making and the environment. CA: Sage Publications.

Stinchfield, B. T., Li, H., \& Du, J. (2009). Sustainable manufacturing strategies and organizational performance in China. International Journal Business Research, 9(6), 46-57.

Tan, X. C., Liu, F., Cao, J., \& Zhang, H. (2002). A decision-making framework model of cutting fluid selection for green manufacturing and a case study. Journal of Materials Processing Technology, 129(1-3), 467-470. http://dx.doi.org/10.1016/S0924-0136(02)00614-3

Trochim, W. (2002). Research methods knowledge base. Atomic Dog Publishing.

US Department of Commerce. (2009). Sustainable manufacturing initiative and public-private dialogue. Retrieved from http://www.trade.gov/competitiveness/sustainablemanufacturing/index.asp

Vachon, S., \& Klassen, R. D. (2008). Environmental management and manufacturing performance: the role of collaboration in the supply chain. Int. Journal of Production Economics, 111(2), 299-315. http://dx.doi.org/10.1016/j.ijpe.2006.11.030

Vickery, S. K., Droge, C., \& Markland, R. E. (1997). Dimensions of manufacturing strength in the furniture $\begin{array}{lllll}\text { industry. Journal of } & \text { Operations }\end{array}$ http://dx.doi.org/10.1016/S0272-6963(97)00012-0

Vinodh, S., \& Joy, D. (2011). Structural equation modeling of sustainable manufacturing practices. Clean Tech Envrion Policy. http://dx.doi.org/10.1007/s10098-011-0379-8

Wagner, M. (2001). A review of empirical studies concerning the relationship between environmental and economic performance of firms: what does the evidence tell us? University of Lüneburg, Centre for Sustainability Management: Lüneburg.

Wagner, M. (2005). How to reconcile environmental and economic performance to improve corporate sustainability: corporate environmental strategies in the European paper industry. Journal of Environmental Management, 76(2), 105-118. http://dx.doi.org/10.1016/j.jenvman.2004.11.021

Wagner, M., \& Schaltegger, S. (2003). How does sustainability performance relate to business competitiveness? Greener Management International, 44, 5-16. http://dx.doi.org/10.9774/GLEAF.3062.2003.wi.00003

Walley, N., \& Whitehead, B. (1994). It's not easy being green. Harvard Business Review, 72(3), 46-52.

Walton, S. V., Handfield, R. B., \& Melnyk, S. T. (1998). The green supply chain: integrating suppliers into environmental management process. Journal of Supply Chain Management, 34(2), 2-11.

Watson, K., Klingenberg, B., Polito, T., \& Geurts, T. (2004). Impact of environmental management system implementation on financial performance. Management of Environmental Quality, 15, 622-628. http://dx.doi.org/10.1108/14777830410560700

White, G. P. (1996). A meta-analysis model of manufacturing capabilities. Journal of Operations Management, 14, 315-331. http://dx.doi.org/10.1016/S0272-6963(96)00096-4

White, J. C., Varadarajan, P. R., \& Dacin, P. A. (2003). Market interpretation and response: the role of cognitive style, organizational culture and information use. Journal of Marketing, 67, 63-79. http://dx.doi.org/10.1509/jmkg.67.3.63.18654 
Wold, H. (1985). Partial least squares. In S. Kotz \& N. L. Johnson (Eds.), Encyclopedia of Statistical Sciences, New York: Wiley.

Xie, S., \& Hayase, K. (2007). Corporate environmental performance evaluation: a measurement model and a new concept. Business Strategy and the Environment, 16(2), 148-168. http://dx.doi.org/10.1002/bse.493

Yamin, S., Gunasekaran, A., \& Mavondo, F. T. (1999). Relationship between generic strategies, competitive advantage and organizational performance: an empirical analysis. Technovation, 19, 507-518. http://dx.doi.org/10.1016/S0166-4972(99)00024-3

Yang, M. G., Hong, P., \& Modi, S. B. (2011). Impact of lean manufacturing and environmental management on business performance: an empirical study of manufacturing firms. Int. Journal of Production Economics, 129, 251-261. http://dx.doi.org/10.1016/j.ijpe.2010.10.017

Zeng, S. X., Meng, X. H., Yin, T. H., Tam, C. M., \& Sun, L. (2010). Impact of cleaner production on business performance. Journal of Cleaner Production, 18, 975-983. http://dx.doi.org/10.1016/j.jclepro.2010.02.019

Zhang, H. C., Kuo, T. C., Lu, H., \& Huang, S. H. (1997). Environmentally conscious design and manufacturing: a state-of-the-art survey. Journal of Manufacturing Systems, 16(5), 352-371. http://dx.doi.org/10.1016/S0278-6125(97)88465-8

Zhu, Q., \& Sarkis, J. (2006). An inter-sectoral comparison of green supply chain management in China: Drivers and practices. Journal of Cleaner Production, 14, 472-486. http://dx.doi.org/10.1016/j.jclepro.2005.01.003

\section{Notes}

Note 1 . We should point out that much of the empirical studies looking at the relationship between sustainability performance and business competitiveness have largely focused on the firm's environmental performance, which is used to represent the company's sustainability performance.

Note 2. In our model the largest number of structural paths is directed at the business performance construct, which is hypothesized to be influenced by 2 constructs - the adoption of sustainable manufacturing practices and competitive advantage.

Note 3. SMEs are defined here as enterprises having fewer than 250 employees (CEC, 1996), and large firms are enterprises with 250 and more employees.

\section{Appendix A}

\section{Demographic Data for the Respondents}

\begin{tabular}{|c|c|c|}
\hline Descriptive (sample size) & Frequency & $\%$ \\
\hline \multicolumn{3}{|l|}{ Country data $(n=76)$} \\
\hline Barbados & 17 & 22.4 \\
\hline Guyana & 7 & 9.2 \\
\hline Jamaica & 17 & 22.4 \\
\hline Trinidad & 28 & 36.8 \\
\hline St. Lucia & 7 & 9.2 \\
\hline \multicolumn{3}{|l|}{ Age of firm $(n=76)$} \\
\hline$<5 \mathrm{yrs}$ & 5 & 6.6 \\
\hline $5-<10 \mathrm{yrs}$ & 9 & 11.8 \\
\hline $10-<15 y r s$ & 30 & 39.5 \\
\hline$>15$ yrs & 32 & 42.1 \\
\hline \multicolumn{3}{|l|}{ Number of employees $(n=75)$} \\
\hline$<50$ & 35 & 46.7 \\
\hline $50-<100$ & 11 & 14.7 \\
\hline $100-<250$ & 19 & 25.3 \\
\hline $250-<500$ & 8 & 10.7 \\
\hline$>500$ & 2 & 2.7 \\
\hline \multicolumn{3}{|l|}{ Job title $(n=72)$} \\
\hline Plant manager & 2 & 2.8 \\
\hline Prod/Ops manager & 19 & 26.3 \\
\hline General/Dept manager & 10 & 13.9 \\
\hline Chairman/CEO/Director/ President & 29 & 40.3 \\
\hline Other & 12 & 16.7 \\
\hline
\end{tabular}




\begin{tabular}{|c|c|c|}
\hline Industry sector $(n=76)$ & 15 & 19.7 \\
\hline Food, beverages and tobacco & 10 & 13.2 \\
\hline Metals, metal products & 14 & 18.4 \\
\hline Petroleum, chemicals and minerals & 8 & 10.5 \\
\hline leather & 8 & 10.5 \\
\hline Wood, wooden products, furniture, paper & 5 & 6.6 \\
\hline Rubber and plastic products & 10 & 13.2 \\
\hline Stone, clay, glass and concrete products & 6 & 7.9 \\
\hline \multicolumn{3}{|l|}{ Machinery, equipment and instruments } \\
\hline \multicolumn{3}{|l|}{ Annual sales in millions of US\$ $(n=69)$} \\
\hline Under 10 & 52 & 75.4 \\
\hline $10-<15$ & 2 & 2.9 \\
\hline $15-<20$ & 4 & 5.8 \\
\hline$>20$ & 11 & 15.9 \\
\hline \multicolumn{3}{|l|}{ Level of export as percentage of total sales $(n=55)$} \\
\hline 0 & 10 & 18.2 \\
\hline$<20$ & 24 & 43.6 \\
\hline $20-40$ & 10 & 18.2 \\
\hline $40-60$ & 8 & 14.5 \\
\hline $60-80$ & 2 & 3.6 \\
\hline$>80$ & 1 & 1.8 \\
\hline
\end{tabular}

\section{Appendix B}

Cross-Loadings of Constructs

\begin{tabular}{llll}
\hline & SMP & BP & CA \\
\hline SMP1 & $\mathbf{0 . 6 3 1 5 9 2}$ & -0.123061 & -0.010964 \\
SMP2 & $\mathbf{0 . 7 4 6 4 2 3}$ & -0.059910 & 0.018348 \\
SMP3 & $\mathbf{0 . 6 0 3 5 2 5}$ & -0.117776 & -0.073776 \\
SMP4 & $\mathbf{0 . 4 3 0 6 5 6}$ & -0.109791 & -0.046179 \\
SMP5 & $\mathbf{0 . 6 0 9 1 5 2}$ & -0.024263 & 0.020353 \\
SMP6 & $\mathbf{0 . 6 4 9 2 2 9}$ & -0.132965 & -0.042786 \\
SMP7 & $\mathbf{0 . 7 1 1 4 9 6}$ & -0.128306 & 0.152886 \\
BP1 & -0.106412 & $\mathbf{0 . 9 1 4 3 0 0}$ & 0.683657 \\
BP2 & -0.119331 & $\mathbf{0 . 9 3 6 7 0 1}$ & 0.620389 \\
BP3 & -0.143424 & $\mathbf{0 . 9 2 5 4 8 9}$ & 0.600900 \\
BP4 & -0.169265 & $\mathbf{0 . 9 0 3 2 5 7}$ & 0.559372 \\
BP5 & -0.134062 & $\mathbf{0 . 8 3 4 6 1 9}$ & 0.579384 \\
CA1 & 0.057318 & 0.475026 & $\mathbf{0 . 8 1 4 2 6 2}$ \\
CA2 & 0.005778 & 0.613283 & $\mathbf{0 . 9 0 4 0 2 5}$ \\
CA3 & -0.004994 & 0.658316 & $\mathbf{0 . 8 7 7 9 5 1}$ \\
CA4 & 0.036172 & 0.598962 & $\mathbf{0 . 8 7 8 7 9 2}$ \\
CA5 & -0.061032 & 0.492822 & $\mathbf{0 . 8 0 2 8 1 8}$ \\
CA6 & -0.045445 & 0.608234 & $\mathbf{0 . 8 0 2 7 3 8}$ \\
\hline
\end{tabular}

\section{Copyrights}

Copyright for this article is retained by the author(s), with first publication rights granted to the journal.

This is an open-access article distributed under the terms and conditions of the Creative Commons Attribution license (http://creativecommons.org/licenses/by/3.0/). 